九州大学学術情報リポジトリ

Kyushu University Institutional Repository

\title{
Analysis of Ozonation Effect on Performance and Water Quality in Closed-System Cooling Tower
}

\author{
Alhamid, M. I \\ Department of Mechanical Engineering, Faculty of Engineering, University of Indonesia \\ Miftah, R. M \\ Department of Mechanical Engineering, Faculty of Engineering, University of Indonesia \\ Rainanda, M. A \\ Department of Mechanical Engineering, Faculty of Engineering, University of Indonesia
}

https://doi.org/10.5109/4742139

出版情報：Evergreen. 8 (4)，pp.896-903，2021-12. 九州大学グリーンテクノロジー研究教育センター バージョン：

権利関係 : 


\title{
Analysis of Ozonation Effect on Performance and Water Quality in Closed-System Cooling Tower
}

\author{
Alhamid, M. I ${ }^{1}$, Miftah, R. $\mathrm{M}^{1}$, Rainanda, M. $\mathrm{A}^{1}$ \\ ${ }^{1}$ Department of Mechanical Engineering, Faculty of Engineering, University of Indonesia \\ Kampus Baru UI Depok, Depok 16424, Indonesia \\ *Author to whom correspondence should be addressed: \\ E-mail: mamak@eng.ui.ac.id
}

(Received April 30, 2021; Revised December 16, 2021; accepted December 16, 2021).

\begin{abstract}
The Cooling tower is an auditor system that is used for the heat transfer process where the heat is not useful anymore. There are several factors in the cooling tower operations that can be observed for cooling tower performance. A large number of bacteria on cooling towers become potential of scale precipitation that can decrease the cooling tower thermal effectivity because the scale will act as an inhibitor for heat transfer rate since the scale has a high value of thermal resistance. The ozone will be injected into the cooling water to reduce the scale precipitation growth rate that can decrease the cooling tower performance. This research intends to find the characteristic of the ozonation effect from cooling tower performance and water quality. The method for water quality checking is the AAS (Atomic Absorption Spectroscopy) method, Titrimetric, Gravimetric, and Spectrophotometric. The output of this research is characteristic of cooling tower performance each day and rate of water quality before and after ozonation and each day. The effectiveness value results obtained in this research was $0.12 \%$ for the lowest value and $8.74 \%$ for the highest value. Ozonation has been proven to improve the water quality rate of cooling towers but has not been proven to improve the performance or effectiveness of cooling towers for an ozonation period of 15 days.
\end{abstract}

Keywords: Cooling Tower Closed System, Heat Exchanger, Ozone

\section{Introduction and background}

Air conditioning is familiar to the era of technology, both on a small scale or home ladder and scales large or industry. Air conditioning devices also vary greatly, ranging from water flowing directly from sources of cooling water that are passed through processes that require cooling and then discharged again, to the use of complex devices such as cooling towers. In essence, water is needed and vital in terms of cooling because water is a heat transfer media.

Cooling towers are generally used for a cooling process at an industrial level. The unit was very instrumental important in the process of industries that operations must be maintained and observed, so the unit is working optimally. On the other side, because of exposure to the surrounding air, the performance of the cooling tower was disrupted by various potential biofouling problems because of microorganisms from the surrounding environment ${ }^{1}$. Because water is the main medium of heat exchange, water quality must be maintained because water is one of the factors that affect the performance of the cooling tower. Inadequate water quality maintenance and bad quality water supplies would cause problems such as the increasing number of bacteria, the emergence of the crust, and corrosion on heat exchanger parts and the basin in the cooling tower. The emergence of these problems will cause a decrease in the level of effectiveness of heat transfer and energy consumption.

One of the causes of the onset of the crust is water addition that is inserted into the basin cooling tower (on the system open or closed) carries the components of hardness such as calcium and magnesium that will accumulate and insoluble commonly called a scale or crust where the tendency of emergence will increase in line with rising temperatures. At the same time, because the cooling water generally flows into metal sleeves or pipes, corrosion problems will also arise ${ }^{2)}$.

All the objects have the value of resistance on heat transfers process or so-called thermal resistance, as well as the crust. So, the growth of the crust on the wall of the heat exchanger will inhibit heat transfers increasing the amount of energy consumed ${ }^{3)}$.

In general, in dressing issues of water quality in the cooling tower is controlling the quality of water using chemicals dissolved in the cooling water so that the material chemicals will kill the bacteria, dissolve the crusts that piling up, and eliminate corrosion. However, the results of water discharged dissolved chemicals in it 
will not be friendly to the environment. So, one of the solutions or an alternative way to control water quality in the cooling tower is by ozone injection. Ozone will act as a bacterial killer where the bacteria are the source of crust $^{2)}$.

On the other hand, the amount of ozone injected in cooling water must be on the right amount, because ozone will be corrosive when the amount of ozone is too much and will have no effect if the amount is less. So, in this study, the amount of ozone will be limited to 234 milligrams per hour and it will be seen how the ozone injection affects the performance of the cooling tower and water quality.

In pilot-scale testing, it is shown that good control of fouling can be attained in ozone-treated cooling water systems. However, as was the case with corrosion control, deposition on the heat exchange surfaces is not determined by the presence of ozone, but by several factors that traditionally influence fouling in a system ${ }^{29}$.

\subsection{Cooling Tower}

In Water-cooled HVAC Systems, cooling towers have a role as heat dissipation or transfers generated by a process with air and water media. In cooling systems, Cooling Tower is a unit that functions to refrigerate hot water from the condenser by direct contact with water or air using a big $\mathrm{fan}^{4)}$. The coolant works by releasing heat generated from the condensation process of a system and in general water is used as a coolant, it is a heat exchanger fluid to remove heat from various systems ${ }^{5}$.

Depending on the way how the ambient air circulates inside the cooling tower, there can be two major types of a wet cooling tower: mechanical and natural draft. In mechanical draft cooling towers, the air is moved by power-driven fan motors to force it to go through the tower. In natural draft cooling towers, the airflow occurs due to the natural pressure difference caused by the difference in density between the cold outside air and the hot humid air inside.

Due to using of water and air as the heat transfer media where the water will evaporate when receiving heat from the process or the media to be cooled, the cooling tower is commonly referred to as an evaporative condenser. In principle, hot fluid in a system is channeled to the cooling tower and recirculated after dissipating heat into the atmosphere ${ }^{6}$. Based on the cooling system there is a Natural Draft and Mechanical Draft, while based on the type of contact there is directly and indirectly. Several characteristics of cooling tower performances have been reported $^{7-20)}$.

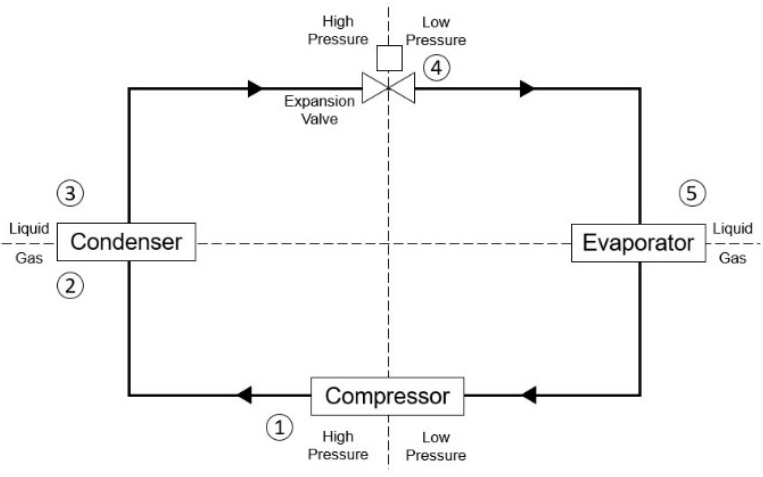

Fig. 1: Schematic of the cooling system.

In this type of cross-flow induced draft cooling tower (shown in Fig. 1), airflow is sucked into the cooling tower with the help of a fan or fan placed after the distribution of water for heat transfer so that the heat transfer distribution area is better than the forced draft cross-flow system. However, this type of cooling tower has a disadvantage that is the difficulty of controlling drift loss compared to the type of forced draft crossflow system ${ }^{2}$.

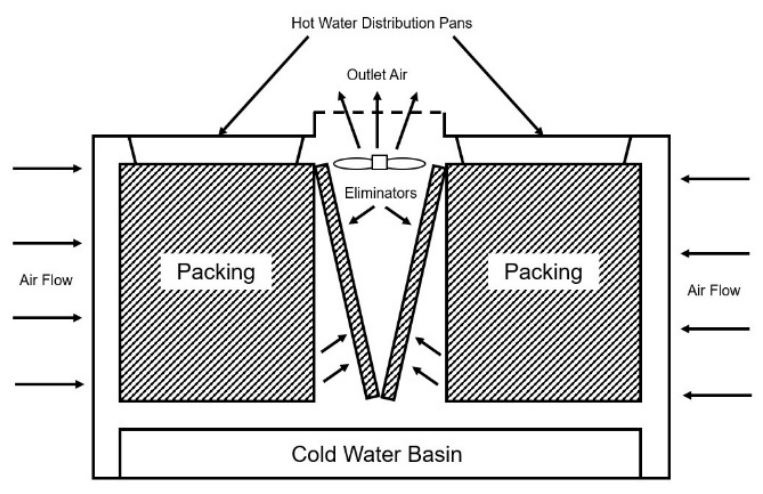

Fig. 2: Crossflow forced draft cooling tower.

In the cooling tower type of crossflow induced draft (shown in Fig. 2), there are also variations of other forms, namely the twin-pack system. This arrangement system activates vertical air output. This type also used multi-cell double intake crossflow to maximize heat transfer. The disadvantage, in this system, must use two eliminators to minimize water coming out of the cooling tower ${ }^{1)}$.

Following are the formulas used in finding the effectiveness value of cooling towers:

\footnotetext{
Cooling Tower Effectiveness $=\frac{\text { Range }}{\text { Range }+ \text { Approach }} \times 100$ [6]

Approach $\left({ }^{\circ} \mathrm{C}\right)=$ Cold Water Temp - Wet Bulb Temp $[5]$ Range $\left({ }^{\circ} \mathrm{C}\right)=$ CWinlet temp - CWoutlet temp $[5]$

EvapLoss $(m 3 / h r)=0.00085 \times 1.8 \times$ circulation rate $(m 3 / h r) \times$ range [5]

Make up Water $(\mathrm{m} 3 / \mathrm{hr})=$ Drift Loss + Evaporation Loss [6]
} 


\subsection{Ozone}

Ozone is a method alternative that is attractive to system processing water multi-chemistry for the tower cooling air. Ozone is a strong biocidal agent against bacteria, viruses, protozoa and with simultaneous oxidation of organic matter results in improved water quality. Characteristics of biocide that powerful is the combination of potential oxidation of the high and defusal through biological membranes. The mechanism of killing ozone is by lysis or direct decay in the cell walls of microorganisms. As a strong biocide, ozone can also be eliminating levels of microorganisms to reduce the concentration of solids organic, and minerals in the system. Crust deposits are mineral solids precipitated which is often a serious problem in the industrial world and generally often found in oil and gas industry equipment, desalination process, boiler and chemical industry (Badr and Yassin, 2007; Lestari, 2004) ${ }^{21-23)}$. Ozone easily oxidizes organic material in bacterial membranes, which weakens cell walls and causes cell damage. Internal cellular/plasma material is released in the external environment, which causes immediate cell death. In contrast, chlorine and oxidizing biocides and other nonoxidizing must be transported across the membrane cell in which they act on the mechanisms of reproduction of nuclear or life enzymes that give reactions in cells. Ozone is more effective than disinfectants because disinfectants need to be used for longer contact times.

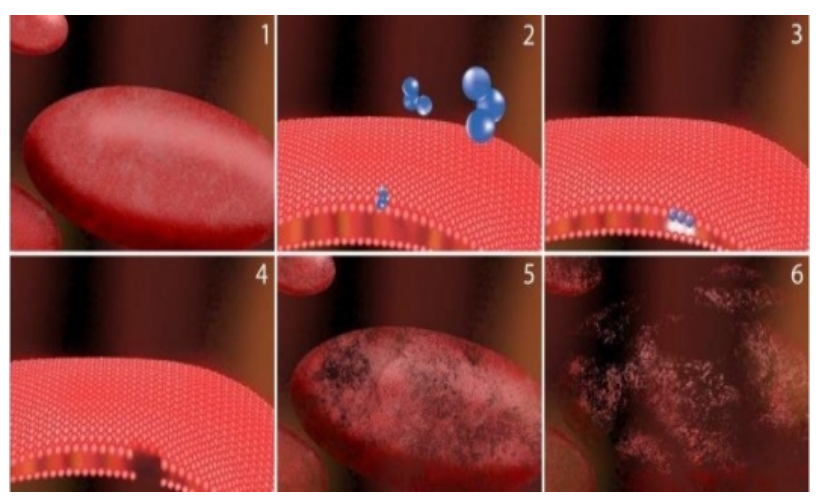

Fig. 3: The mechanism of destruction of bacterial cells by ozonolysis.

The description of Fig. 3 is as follows:

1. The computer captures bacterial cells

2. Ozone molecules approach the bacterial cell wall

3. Penetration and formation of holes in the cell wall of bacteria by ozone

4. Effects of ozone on cell walls

5. Bacterial cells after contact with ozone molecules

6. Cell destruction by ozone (lysis)

Microorganisms, especially bacteria and viruses, develop immunity to chemicals when used for long periods, hence biocides need to be changed or replaced for effective microorganism control. No microorganism is known to have developed resistance to ozone to date, thereby eliminating the need to replace biocides ${ }^{24)}$.

\subsection{Water Quality}

When make-up water contains high concentrations of inorganic salt, crust from minerals can grow and become sediment which serves as an insulator or inhibitor of heat transfer rate in the heat exchanger pipe or heat exchanger. When the deposition of this salt is heavy, heat transfer can be inhibited. An increase in temperature condensing will cause a reduction in cooling capacity and an increase in energy consumption. Calcium (Ca) becomes the main problem when calcium settles at hotter temperatures and on the onset of carbonate alkalinity will be converted into calcium carbonate scale. Organic acids and polymers are commonly used to avoid and eliminate scale deposits.

The use of acid should be at the heart - the heart because the condition of the acid can cause corrosion and premature degradation of cooling tower units ${ }^{25}$. Because the crust grows due to the deposition of solid material that is suspended in water, we must measure the value of TDS or total dissolved solids to determine the value contained in water quality. This will illustrate that the lower the TDS value, the better the quality of water, and the possibility of precipitation will decrease. To measure salinity or salinity in water quality, it can be done by measuring electrical conductivity ${ }^{26)}$.

Bacteria that are commonly found in cooling towers are Legionella types of bacteria. Legionella is deadly and has been a problem in cooling towers for a long time.

The warm water temperature of the cooling tower and the presence of other biological material and organic debris cause the growth of Legionella bacteria. Many ways have been done so that the Legionella bacteria are not resistant or immune to a mixture. These bacteria can be stubborn because these bacteria can survive in the womb tend to Chlorine and Bromine with concentration high, two types of materials chemistry that are most used for quality control of water in the cooling tower. Ozone and Chlorine Dioxide can be an alternative to the effective control of water quality for bacteria Legionella but has not spread widely due to the cost of the tools are still expensive and expert techniques needed ${ }^{25)}$.

\section{Method and experimental setup}

First, created auxiliary channels which have function as a place for injecting ozone into the water flow in the cooling tower.

The supporting components are then installed in the water channel of the closed system. These components include bypasses, valves, flow meters, a Mazzei injector, UV rays, and ozone generators.

After installation, the water flow from the cooling tower basin to the auxiliary water channels in the closed-circuit cooling tower system must be checked to ensure that there 
are no leaks and blockages in the pipes.

Before the operation starts, all the equipment used must be checked first. Equipment that uses electrical energy such as ozone generators, UV light, and water pumps must be checked in the off-switch position before connecting to the power supply. After checking, turn on the water pump to start circulation through the auxiliary water channel.

The ozone generator and UV light are then turned on. The ozone generator is set up by time so that it will automatically turn off after 2 hours. After 2 hours of operation, the ozone generator needs a 1-hour break before beginning another 2 hours cycle. This is done continuously for 8 hours.

Once all the necessary tools are working either the solubility of the ozone in the flow or the amount of flow in the water channel may take a little time to stabilize

Data collection was carried out in 2 phases, the first was before being injected with ozone and the second was after being injected with ozone. This division aims to see the differences that occur in the closed system cooling tower before ozone injection and after ozone injection.

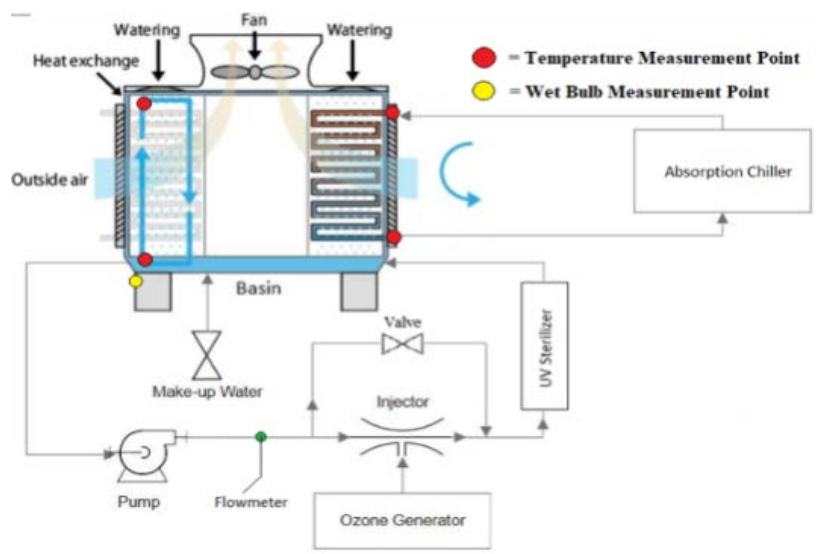

Fig. 4: Schematic of experimental setup.

Data is collected when the solubility of ozone and the flow of water in the auxiliary channel in the closed-circuit cooling tower system have stabilized.

Temperatures are taken at the second measurement point at the top of the closed cooling tower system and from water in the basin by using a thermocouple type - $\mathrm{k}$ that relates to Lab View software. Lab View software reads the temperature value in digital form and directly stores it in .csv or .txt.

Collecting data temperature of the cooling tower by asking the online data that has been recorded to Mr. Ferry's laptop. Then, the data flow rate of the cooling tower closed system is taken manually by looking at the flow meter installed on the pipe, but the value of the flow rate of cooling water towers is enclosed. The system is relatively constant.

The wet-bulb temperature value is taken from the Rh meters installed in the closed-circuit cooling tower system. The data obtained is the $\mathrm{Rh}$ value and dry bulb temperature value. A psychrometric chart is then used to change the Rh and dry bulb temperature values into wetbulb temperature.

In this study, ozone was tested using the iodometric titration method. The purpose of the test was to determine the ozone production flow rate of ozone generated from the Ozonator to be used.

\section{Results and Discussion}

\subsection{Ozone Productivity}

Ozone testing was carried out by the Laboratory of the Department of Chemical Engineering, University of Indonesia, and the results of ozone productivity were 234 milligrams per hour. This result is different from the specifications of the existing ozone generator, which is 3 grams per hour. The results of ozone productivity which is lower than the original specifications can be caused by the air condition around the ozone plant and the conditions of the ozone generator itself. The condition of the ozone generator can be influenced by the condition of the ozone generator storage during not being used and the laying of the ozone generator when in use. With this result, it can be stated that the ozone generator which is more than one year old (counting from the purchase) is not at its optimal performance.

Table 1. Ozone productivity test results.

\begin{tabular}{|c|c|c|c|c|c|c|c|}
\hline \multirow[b]{2}{*}{ NO } & \multicolumn{2}{|c|}{ VOLUME TIO (mL) } & \multirow[b]{2}{*}{$\mathrm{BM} \mathrm{O}_{3}$} & \multirow{2}{*}{$\begin{array}{l}\text { TIME } \\
\text { (MINUTES) }\end{array}$} & \multirow{2}{*}{$\begin{array}{l}\text { M TIO } \\
(\mathrm{mol} / \mathrm{L})\end{array}$} & \multirow[b]{2}{*}{$\mathrm{fp}$} & \multirow{2}{*}{$\begin{array}{l}\text { O3 PRODUCTVTYY } \\
\text { (mgjam) }\end{array}$} \\
\hline & Upstream & Dounstream & & & & & \\
\hline & \begin{tabular}{|l|}
1.43 \\
\end{tabular} & 0.20 & 48 & 10 & 0.1 & 10 & 234.72 \\
\hline & & & & & & & \\
\hline
\end{tabular}

\subsubsection{Range Value Analysis}

The range value is the difference value or the difference between the temperatures of the entry of water that carries heat into the cooling tower with the cooled water coming out of the cooling tower. Value range will affect the value of the effectiveness of a cooling tower, wherein when the value of the range of is high then the value of the effectiveness of a tower cooling means high where tower coolers that work well in throwing heat of fluid taken.

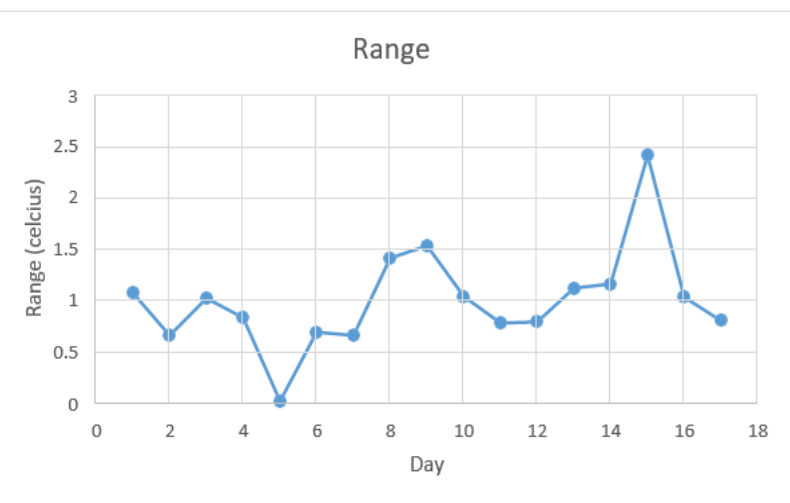

Fig. 5: Value of Range per day. 
Equation: Range $\left({ }^{\circ} \mathrm{C}\right)=$ CWinlet temp - CWoutlet temp

As shown in Fig. 5, the range value of the cooling tower before ozone injection on the first day to the 11th day and after ozone injection on the 12th day to the 17th day. In this study, the range values obtained illustrate the increase and decrease or fluctuations at the time before and after ozone injection. In conclusion, judging by the value of this range, ozone injection in this cooling tower has not been able to help increase the range value of the cooling tower because the Ozonation can not decrease the fouling resistance significantly which becomes one of the factors that inhibit the heat transfer process.

\subsubsection{Analysis of Approach Value}

The value approach is the value of the difference or differences in the value of the outlet temperature of the cooling tower wet-bulb temperature of the ambient temperature around the cooling tower. A low approach value symbolizes the ability of a good cooling tower when viewed from the wet ball temperature value.

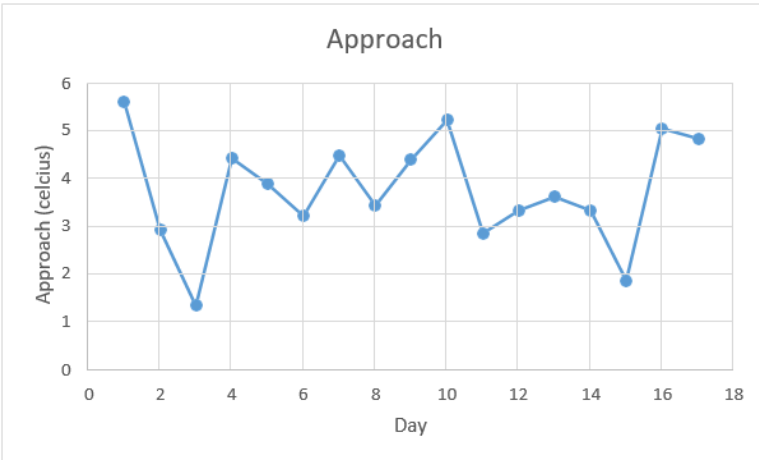

Fig. 6: Graph of approach values. Equation: Approach $\left({ }^{\circ} \mathrm{C}\right)=$ Cold Water Temp - Wet
Bulb Temp

As shown in Fig. 6, the approach value obtained in this study is fluctuating because the approach value has increased or decreased just before ozone injection and after ozone injection. Ozone injection began on the 12th day and so on until the 17th day. Based on the graph obtained, it can be concluded that ozone injection has not been able to influence or decrease the approach value for the cooling tower because the Ozonation can not decrease the fouling resistance significantly which becomes one of the factors that inhibit the heat transfer process.

\subsubsection{Drift Loss Value Analysis}

Value drift loss is the value of the loss of mass loss in the cooling tower water is lost due to airborne is sucked by a fan or a fan of the cooling tower. The value of the drift loss is generally provided by the manufacturer who made the cooling tower. If the value is unknown, for the induced draft cooling tower the $0.3 \%$ value of the cooling tower flowrate is used. From the equation, the value of drift loss is $0.204 \mathrm{~m} 3$ / h with a constant value.

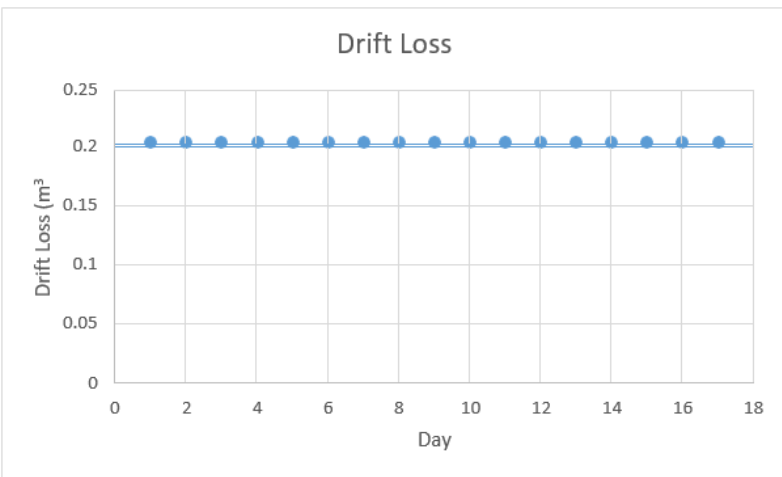

Fig. 7: Graph of drift loss values.

\subsubsection{Analysis of Evaporation Loss Value}

Value evaporation loss is the value of the loss suffered as a result of the mass loss of the cooling tower water to evaporate into the air due to contact with heat exchanger pipes that carry heat to be removed or evaporated due to ambient temperature. As a result of evaporation loss is the loss of water mass so that water from the cooling tower basin must be filled when the water has begun to decrease. The higher the value of the range, the greater the evaporation loss value, this indicates that the cooling tower performance will be better when the evaporation loss value is greater.

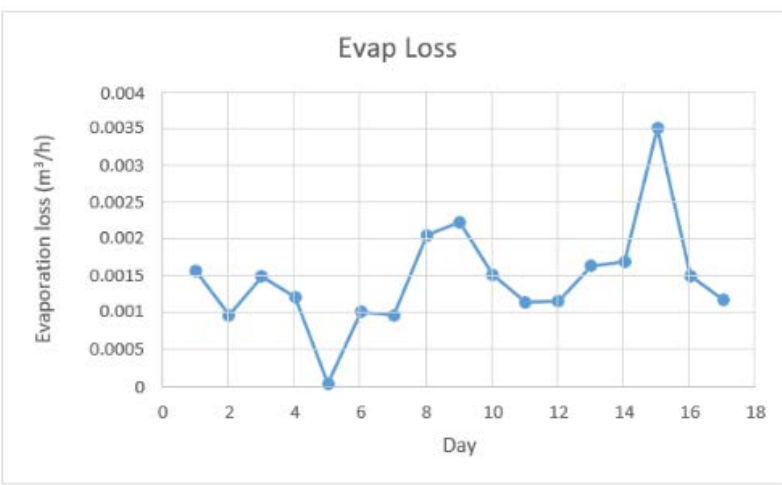

Fig. 8: Graph of evaporation loss values.

Equation: EvapLoss $(\mathrm{m} 3 / \mathrm{hr})=0.00085 \times 1.8 \times$ circulation rate $(\mathrm{m} 3 / \mathrm{hr}) \times \mathrm{x}$ range

As shown in Fig. 8, the value of evaporation loss is obtained fluctuate or increase and decrease in the moments before injected ozone and after injection of ozone because the value of evaporation loss is also influenced by the value of the range where the value range on research this is also volatile. It can be concluded that ozone injection has not been able to increase the value of evaporation loss. 


\subsubsection{Analysis of Make-up Water Value}

The make-up water value is the value of the amount of water mass that must be added when the cooling tower loses water due to drift loss and evaporation loss. A high make-up water value represents a good cooling tower performance because the make-up water value is directly proportional to the range value where the range value is directly proportional to the cooling tower effectiveness value.

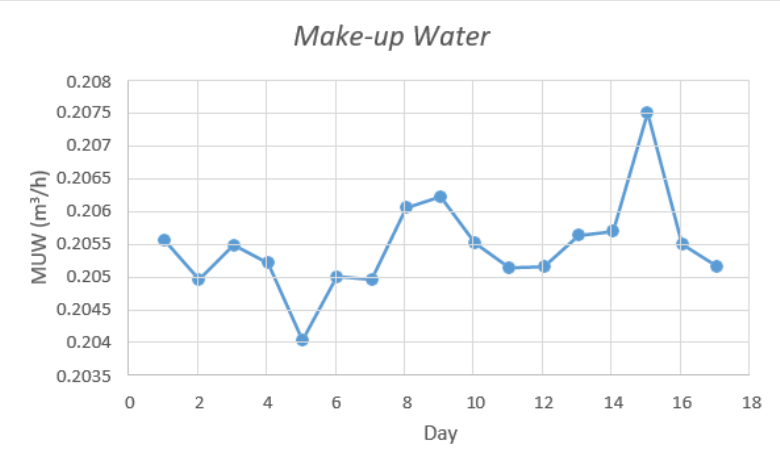

Fig. 9: Graph of make-up water values.

Equation: Make up Water $(\mathrm{m} 3 / \mathrm{hr})=$ Drift Loss + Evaporation Loss

As shown in Fig. 9, the value of the make-up water obtained has increased or decreased or fluctuated but with a relatively small range of data with the smallest value of $0.204 \mathrm{~m} 3$ / h and the highest value of $0.207 \mathrm{~m} 3$ / h. From the data obtained, it can be concluded that ozone injection has not been able to increase the make-up water value of the cooling tower.

\subsubsection{Effectiveness Value Analysis}

The effectiveness value of the cooling tower is a value that can be used to represent the performance of a cooling tower. Based on the similarities that exist based on the theory, the value of the effectiveness of the cooling tower will be directly proportional to the value range and will be inversely proportional to the value approach. The higher the value of the effectiveness of a cooling tower, the better the performance of the cooling tower.

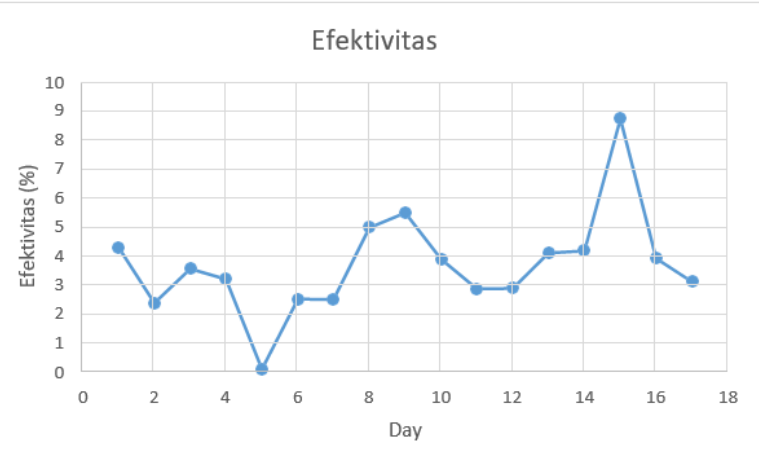

Fig. 10: Graph of the effectiveness of cooling towers.
Equation: Cooling Tower Effectiveness $=\frac{\text { Range }}{\text { Range+Approach }} \times 100$

As shown in Fig. 10, it can be seen that the data obtained from fluctuating due to an increase and decrease in the moments before injection of ozone on the first day until the 11th or after the injection of ozone on day 12 to day 17 Based on the graph above, it can be concluded that ozone injection for 6 hours per day for 15 days in the cooling tower has not been able to increase the effectiveness which is a parameter of the performance of the cooling tower with data seen for 6 days.

The results of research that have not been able to improve the effectiveness or performance of the cooling tower can be influenced by several factors, one of which is the ozone dose that has not been able to remove the scale that is in the heat exchanger pipe where the scale has been around for a long time and not all are released when cleaning the cooling tower with acid.

\subsubsection{Analysis of Electrical Conductivity Value (Electric Conductivity)}

The value of electrical conductivity is the value of water quality that illustrates how well the water can conduct electricity. Water that can conduct electricity means it has a metal solid contained therein so that it can cause deposits that will reduce the performance of the cooling tower. Therefore, we want to reduce the value of electrical conductivity in water.

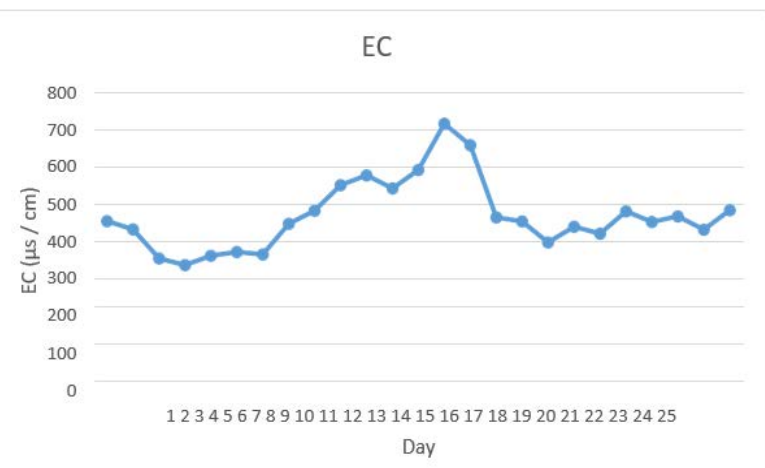

Fig. 11: Value of electrical conductivity.

As shown in Fig. 11, it can be seen that the value of the electrical conductivity increases at the time before the injected ozone in which indicates the increase in the number of ions of metal that is dissolved which have the characteristics of natural as a conductor of electricity. While the electrical conductivity has decreased after ozone injection (starting from day to 14) and experienced stagnation or a value that tends to remain on day 18 with a slight fluctuation until the 25th day. It can be concluded that ozone injection for 15 days can reduce the value of the electrical conductivity of water from the cooling tower. 


\subsubsection{Analysis of the $\mathrm{pH}$ value of water}

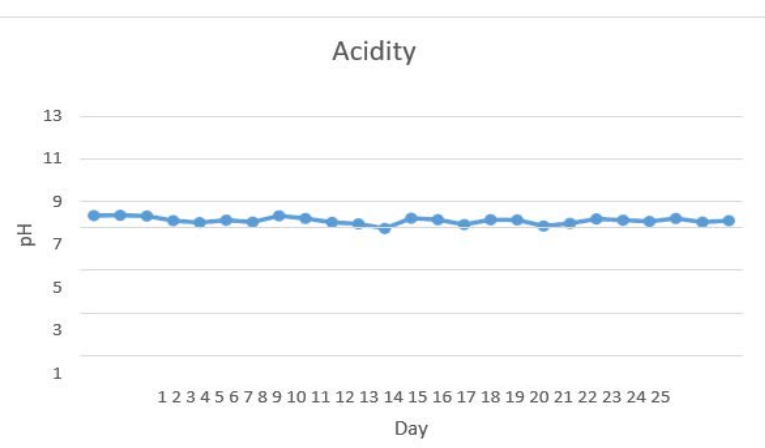

Fig. 12: Graph of $\mathrm{pH}$ values.

As shown in Fig. 12, the data obtained on the acidity value of water quality from the cooling tower experiences fluctuating values in the $\mathrm{pH} 8$ range both before and after ozone injection. This illustrates that the acidity of the water at the time of the study is less than what we expect than a $\mathrm{pH}$ value of 8 . This value is desirable in research this is the value of $\mathrm{pH} 7$ for ozone will work with an optimum at $\mathrm{pH} 7$ as shown on the basic theory.

\subsubsection{TDS (Total Dissolved Solids) Analysis}

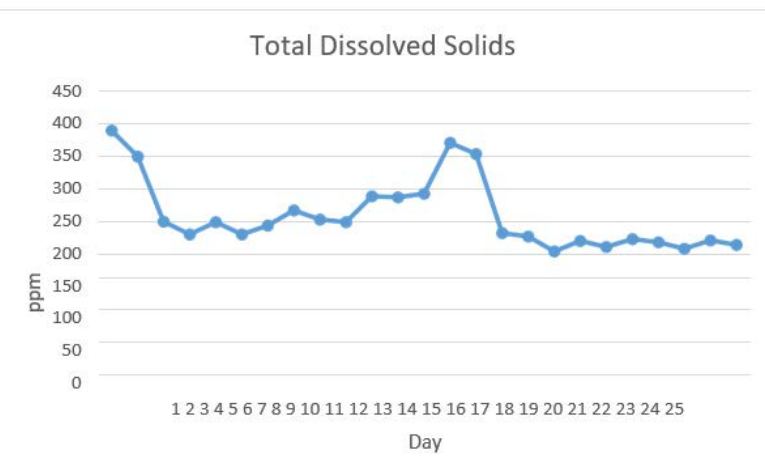

Fig. 13: Graph of TDS values.

As shown in Fig. 13, the value of TDS before the ozone injection (the first day to the 14th) experiences an upward trend. Once injected ozone in the day to 14 , the value of TDS decreased until day 18 and stagnated until day 25. This illustrates that the injection of ozone can reduce the number of dissolved solids in the cooling tower water due to the trend of the graph above that tend to go down.

\section{Conclusions}

1. The effectiveness value obtained in this study has the lowest value of $0.12 \%$ and the highest value of $8.74 \%$.

2. The value of water mass lost in this study has the lowest value of $0.204 \mathrm{~m}^{3} / \mathrm{h}$ and the largest value of $0.2075 \mathrm{~m}^{3} / \mathrm{h}$.

3. Injection of ozone in cooling towers every 6 hours per day for 15 days is proven to improve the quality of the water in the tower cooling seen from the data quality of the water that is taken for 6 days.

4. Ozone injection in the cooling tower every 6 hours per day for 15 days has not been proven to improve the performance of the cooling tower in terms of performance data retrieval for 6 days.

\section{Acknowledgments}

The authors would like to thank the Directorate of Research and Community Engagements Universitas Indonesia (DRPM UI) who made this research possible supported by Hibah PITTA 2019 funded with contract number 2489/UN2.R3.1/HKP.05.00/2018.

\section{Nomenclature}

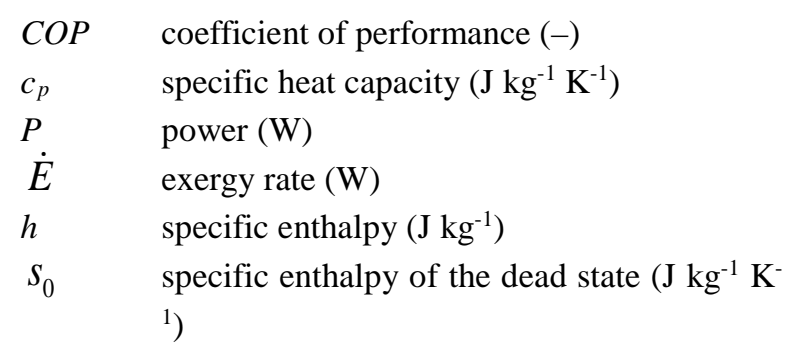

Greek symbols

$\begin{array}{ll}\delta & \text { exergy defect (-) } \\ \eta & \text { efficiency (-) }\end{array}$

$\begin{array}{ll}\begin{array}{ll}\text { Subscripts } \\ 2^{\text {nd }}\end{array} & \text { Second Law } \\ \text { Carnot } & \text { Carnot } \\ \text { Dis } & \text { discharge } \\ e & \text { exit }\end{array}$

\section{References}

1) Sung, S.-K., S.-H. Suh, and D.-W. Kim, Characteristics of cooling water fouling in a heat exchange system. Journal of mechanical science and technology, 22(8): p. 1568-1575 (2008)

2) Hill, GB, Cooling Towers Principles and Practice (1990)

3) M. V. H. Satish, Kumar., Performance Analysis of Cooling Tower. International Journal of Engineering Trends and technology (2016)

4) John, H., Cooling Towers System Guidance for Energy Operations. Kelcroft E \& M Limited, p. 1-6 (1998)

5) Sultan M El-Sharkaw I Miyazaki T Saha B Koyama S, Experimental Study on Carbon Based Adsorbents for Greenhouse Dehumidification, Evergreen, doi.org/10.5109/1495157

6) McNicholas, P.D., The Use of Ozone in Cooling Towers (2002).

7) Shahzad, Muhammad Wakil, Kyaw Thu, Bidyut 
Baran Saha, Kim Choon Ng, An Emerging Hybrid Multi-Effect Adsorption Desalination System, Evergreen, 1(02) pp. 30-36 (2014)

8) Alhamid, M.I., S. Bismo, F. Nainggolan and A. Yatim, Analysis of the effectiveness of ozonation on corrosion and bacteria on closed system cooling towers, AIP Conference Proceedings 2062, 020046 (2019)

9) Alhamid, M.I., Bismo, S., Kelvin, R., Yatim, A., Performance analysis and water quality after ozone application in closed circuit cooling tower systems, AIP Conference Proceedings 2062, 020043 (2019)

10) M.I. Alhamid, et al. "Study on the Effectiveness of Ozonation Technique in Preventing Scale Precipitation on Closed System Cooling Towers.” Evergreen, 6(1), p. 65-70 (2019)

11) Karamah, E. F., S. Bismo, and W. W. Purwanto. "Significance of Acoustic and Hydrodynamic Cavitations in Enhancing Ozone Mass Transfer." Ozone: Science and Engineering 35 (6): 482-488 (2013)

12) Karamah, E. F., R. Ghaudenson, F. Amalia, and S. Bismo. "Disinfection of Escherichia Coli Bacteria using Hybrid Method of Ozonation and Hydrodynamic Cavitation with Orifice Plate.”. zAIP Conference Proceedings Volume 1904, Article number 020075, 3rd International Symposium on Applied Chemistry 2017, ISAC 2017

13) Taha, Ahmed, El-Sousy K, Helles R, Helles S. Elimination of Remazole Blue-B by Advanced Oxidation Methods. Journal of Al Azhar University Gaza Vol. 8, 55-64 (2006)

14) Alaton, IA Balcioglu, DW Bahnemann. Advanced oxidation of a reactive dyebath effluent: Comparison of O3, H2O2 / UV-C and TiO2 / UV-A processes. Water Res. 36. 1143-1154 (2002)

15) Indrawati. Papers solution decolorize Remazol Brilliant Blue Using Ozone Electrolysis results. Semarang: Department of Chemical Engineering, Faculty of Engineering, University of Diponegoro (2008)

16) Bott, T.R., Fouling of heat exchangers. Elsevier (1995)

17) Pope, D.H., et al., The effect of ozone on Legionella pneumophila and other bacterial populations in cooling towers. Current Microbiology, 10(2): p. 8994 (1984)

18) Lezcano, I., et al., Ozone inactivation of microorganisms in water: gram positive bacteria and yeast. Ozone: science \& engineering, 23(2): p. 183187 (2001)

19) Ministry of Environment. Regulation of the Minister of Environment of the Republic of Indonesia Number 5 of 2014 regarding Standard Wastewater. Jakarta (2014)

20) Sastrosudiro, BS, et al., Control Strategy of Solar Thermal Cooling System under the Indonesia Climate
(2016)

21) Badr, A. and A. A. M. Yassin., 'Barium Sulfate Scale Formation in Oil Reservoir During Water Injection at High-Barium Formation Water', Journal of Applied Sciences, 7(17), pp: 2393-2403. (2007)

22) Lestari, D. E., G. R. Sunaryo, Y. E. Yulianto, S. Alibasyah dan S. B. Utomo, Kimia Air Reaktor Riset G.A.Siwabessy, Makalah Penelitian P2TRR dan P2TKN BATAN, Serpong (2004)

23) Lestari, D.E., Kimia Air, Pelatihan Operator dan Supervisor Reaktor Riset, Pusat Pendidikan dan Pelatihan BATAN. Serpong (2008)

24) Menon, PM, Ozonation - The Answer to High Energy and Water Savings in Airconditioning Systems. IBSFM. PS5 1220. (2003)

25) W. Stanfor, Herbert., HVAC Water chillers and Cooling Towers (2003)

26) Bauder, TA, Waskom, RM, Sutherland, PL, Davis, JG "Irrigation Water Quality Criteria." Crop Series: Irrigation, no. 0.506.

27) Rouf, Rifat Ara, et al. "Energy Management and Heat Storage for Solar Adsorption Cooling." Evergreen, 3(2), p. 1-10 (2016)

28) Fauziah J, Miyazaki T, Saha B, Koyoma S, Overview of Absorption Cooling System based on Activated Carbon - Alcohol Pair, Evergreen, 2(1), pp.30-40 (2015)

29) Strittmatter, R. J., Yang, B., Johnson, D.A., "Application of Ozone in Cooling Water Systems.", NACE Corrosion 1992 (1992) 